Témoigner Témoigner. Entre histoire et mémoire

Getuigen Revue pluridisciplinaire de la Fondation Auschwitz

$121 \mid 2015$

Violences radicales en scène

\title{
Lieven Saerens. Onwillig Brussel. Een verhaal over Jodenvervolging en verzet
}

Brussel: Davidsfonds/Cegesoma, 2014

Lieven Saerens, Rachel, Jacob, Paul et les autres. Une histoire des Juifs à Bruxelles

\section{Daniel Weyssow}

Traducteur : Gorik de Henau

\section{(2) OpenEdition}

Journals

Édition électronique

URL : https://journals.openedition.org/temoigner/3646

DOI : $10.4000 /$ temoigner.3646

ISSN : 2506-6390

Cet article est une traduction de :

Lieven Saerens. Rachel, Jacob, Paul et les autres. Une histoire des Juifs à Bruxelles - URL : https:// journals.openedition.org/temoigner/3638 [fr]

Éditeur :

Éditions du Centre d'études et de documentation Mémoire d'Auschwitz, Éditions Kimé

Édition imprimée

Date de publication : 1 octobre 2015

Pagination : 176-177

ISSN : 2031-4183

Référence électronique

Daniel Weyssow, «Lieven Saerens. Onwillig Brussel. Een verhaal over Jodenvervolging en verzet»,

Témoigner. Entre histoire et mémoire [Online], 121 | 2015, Online op 01 octobre 2016, geraadpleegd op 03 février 2022. URL: http://journals.openedition.org/temoigner/3646 ; DOI: https://doi.org/10.4000/ temoigner.3646

Ce document a été généré automatiquement le 3 février 2022

Tous droits réservés 


\title{
Lieven Saerens. Onwillig Brussel. Een verhaal over Jodenvervolging en verzet
}

\author{
Brussel: Davidsfonds/Cegesoma, 2014 \\ Lieven Saerens, Rachel, Jacob, Paul et les autres. Une histoire des Juifs à \\ Bruxelles
}

Daniel Weyssow

Traduction : Gorik de Henau

\section{RÉFÉRENCE}

Lieven Saerens, Onwillig Brussel. Een verhaal over Jodenvervolging en verzet, Brussel, Davidsfonds/Cegesoma, 2014.

1 Zoals Rudi Van Doorslaer, directeur van het Studie- en Documentatiecentrum Oorlog en Hedendaagse Maatschappij (CEGESOMA), in de inleiding aangeeft, kwam dit werk tot stand als gevolg van de excuses die de toenmalige Brusselse burgemeester Freddy Thielemans op 2 september 2012 aanbood 'voor de collaboratie van de Brusselse overheden aan de Jodenvervolging' door de bezetter, exact zeventig jaar voordien. We herinneren eraan dat de Senaat om die kwestie op te helderen tien jaar eerder bij CEGESOMA een studie had besteld over de mate waarin de Belgische autoriteiten hadden meegewerkt aan de nazipolitiek gericht op de uitroeiing van de Joden. Wie meer wil weten over dit onderwerp kan terecht bij het indrukwekkende werk Gewillig België: overheid en Jodenvervolging tijdens de Tweede Wereldoorlog (Rudi van Doorslaer (red.), Emmanuel Debruyne, Frank Seberechts \& Nico Wouters, Meulenhoff/Manteau: Antwerpen, 2007), waaraan Lieven Saerens meewerkte met een hoofdstuk over de antiJoodse politiek van nazi-Duitsland.

2 De auteur, een historicus die aan de KU Leuven studeerde, had trouwens in het raam van zijn in 2009 gepubliceerde doctoraat de houding van de Antwerpenaren tegenover de Joden in de periode 1880-1944 onderzocht. In Onwillig Brussel. Een verhaal over 
Jodenvervolging en verzet bestudeert hij het traject van de bedachtzame en moedige personen die vanaf het prille begin van de twintigste eeuw in onze hoofdstad een schuilplaats hadden gevonden, op de vlucht voor pogroms, armoede en nazi's. Natuurlijk spitst het onderzoek zich toe op de bezettingsjaren.

De auteur bakent het Brusselse Yiddishland (om zijn term te gebruiken) af op basis van documenten en getuigenissen van een twintigtal families, waarvan de meeste zich in de Marollenwijk hadden gevestigd, en geeft zo in zijn fresco een beeld van hun odyssee. Je moet wel onder de indruk zijn van het precieze relaas, dat van begin tot einde regelmatig en volstrekt rechtlijnig verloopt, en waaraan valt te merken met wat voor complexe problemen de immigranten af te rekenen kregen. De auteur staat stil bij de meest onthullende momenten uit het leven van verschillende personen, waardoor het kloppende hart van een hele gemeenschap zichtbaar wordt via de volgende families (in de volgorde waarin ze in het boek aan bod komen): Halter, Elberg, Gottcheiner, Mirowski, Prowizur, Englert, Sztejnberg, Gotovitch, Zimmerman, Cyngiser, Prigogine, Perelman, Jospa, Livschitz, Sterno, Kalb-Beller, Liebman, Errera, Hirsch, Van den Berg, Stern, Dobrzynski, Gutfraynd, Nussbaum, Gottschalk, Gronowski, Ullmann, Flinker, Glogowski, Van Praag, Mayer, Swierk. Nog veel meer personen krijgen een vermelding; de index telt wel tweehonderd namen.

De verhalen spelen zich af in een afgesloten wereld waarin de moeilijkheden, gevaren en risico's alomtegenwoordig waren, ondanks de ondersteuning in opvang en vluchtelingenhulp die werd geboden door vooroorlogse verenigingen en groeperingen die tijdens de oorlog in het grootste geheim opereerden. De invasie op 10 mei 1940, gevolgd door de vestiging van het hoofdkwartier van het Duitse leger en zijn politiediensten, mondde uit in het gecontroleerde bestuur van het land en het toezicht op 's lands inwoners, in de allereerste plaats de Joodse bevolking. Via bevelen en verordeningen spande de bezetter vervolgens de valstrik waarin hij die bevolking trachtte te vangen om naar Auschwitz te deporteren. Met steun van diverse lokale helpers zou de dodendans schrikwekkende resultaten hebben. Zo was er het Jodenregister van de gemeentelijke overheden - zonder had de bezetter nooit zo vlot zijn deportatieprogramma kunnen opzetten - en de gedwongen oprichting van de Vereniging van Joden in België, maar ook de verplichting tot het dragen van de ster en de convocaties om zich aan te bieden in de Dossinkazerne in Mechelen. Na de razzia's werd de mensenjacht nog opgevoerd via ontelbare ontvoeringen en aanhoudingen, op straat en thuis. In het boek komen de strategieën aan bod die werden gebruikt om de door Berlijn bepaalde deportatiequota te halen. We mogen niet vergeten dat minder dan 5 procent van de 25484 Joden en 352 Roma die vanuit België en Noord-Frankrijk via Mechelen naar de concentratie- en vernietigingskampen van de nazi's werden gedeporteerd, de oorlog overleefden. Daarnaast beschrijft de auteur bepaalde acties van verzet en partizanen; zij gingen ondergronds, trachtten de schokken te breken en verweerden zich met succes tegen de bezetter.

5 Gezien de grote hoeveelheid aan informatie die erin is verwerkt, is dit voor iedereen toegankelijke boek een uitstekende synthese van wat de Joodse vluchtelingen in Brussel meemaakten. Om het aantal pagina's te reduceren en de lectuur te vergemakkelijken werden de voetnoten vervangen door een beknopte bibliografie en een index van de vermelde namen, achteraan in het werk. We wijzen ook op de pedagogische manier waarop het laatste hoofdstuk is uitgewerkt; daarin bevinden zich een vragenlijst (met antwoorden) en overhoringen over hedendaagse thema's 
(extreemrechts, negationisme, vreemdelingenhaat). Dankzij die praktische toepassingen is het werk ook vandaag bijzonder relevant. 